

East African School of Higher Education Studies \& Development
Makerere Journal of Higher Education

ISSN: $1816-6822 ; 10$ (2) (2019) 157 - 170

DOI: http://dx.doi.org/10.4314/majohe.v10i2.12

(C) The Author(s) 2019

Reprints \& permission: EASHESD

http://ajol.info/majohe

\title{
Analysis of the Teacher Training System in Ethiopia with Specific Reference to Areas for Improvement
}

\author{
Teklu Tafesse Olkaba ${ }^{1, *}$, Adula Bekele Hunde ${ }^{1}$, Tadesse Regassa Mamo ${ }^{1}$, Gemechis \\ File Duresa ${ }^{1}$, Dereje Daksa Keno ${ }^{1}$ \\ ${ }^{1}$ Jimma University [*Corresponding author: teklu252@yahoo.com]
}

\begin{abstract}
The objective of this study was to analyse the teacher training system in Ethiopia with the view to identify opportunities for revitalization. The analysis started with a desk review before proceeding to a survey. This was conducted in South West Ethiopia. The analysis of the teacher training system was framed in line with teachers' social status of teaching profession; modalities of the teacher education program; program structure and curricula; teacher education and school partnership; qualification requirement; processional development and teacher competences. The findings confirm weak social status of the teaching profession and statistically significant difference between students' and teachers' perception of teacher competence. Gaps in the structure and curricula of teacher education programmes; school partnerships; and teacher qualification requirements are noted. Review of teacher training programmes, improving teachers' benefits and establishment of a quality assurance mechanism in teacher education are recommended.
\end{abstract}

Keywords: Teacher training; Curriculum reform; Quality assurance.

\section{$1 \quad$ Introduction}

Ethiopia is envisaging in improving the quality of teacher training since the endorsement the education and training policy of 1994. Several reforms and strategies were designed to strengthen the quality of general education in Ethiopia with a special focus on improving the capacity of teacher training colleges at regional and national levels. According to Ministry of education (1994) the main priority action areas identified and targeted in the policy were: certification of teachers, the balance between subject matter and professional knowledge, in service and pre-service modality of teachers development, institution of career structure for professional development, intensifying the 
teaching profession, the autonomy of teacher training institutions, inclusion of special needs education in teacher preparation, the medium of instruction in preprimary and primary education, the decentralization of educational management and the funding of general education with cost sharing at the higher level (MOE, 1994).

Currently, the Ministry has established centres of excellence in education in selected universities and provided them with the responsibility of feeding policy makers and implementers with the evidence-based action points that can improve the preparation and development of quality teachers for quality students' learning (MOE, 2008). The analysis is to draw lessons for teacher development and providing input into assessment in teacher-development. The analysis is important for the revitalization of new models of teacher-training programs in the country.

\subsection{Problem}

The Ethiopian education and training policy endorsed since 1994 was reasonably comprehensive in the sense that it refers to the different levels of training and the various teacher education components to deliver the educational services the country envisioned. Later on, there were strategies to further strengthen the provision of educational services, focusing on improvement of teacher competences, raising the standard of teacher training institutions, development of in-service training program for teachers and establishing an attractive and realistic career structure for teachers (Hunde, 2014).

Programs to upgrade the qualifications of teaching personnel in the regions were launched. Apparently, however, there is considerable work that is yet to be done (MOE, 2003). The glaring issues around the teacher education programs are the gap between quality and quantity of teachers at all levels, the increasing trends of attrition, the low level of teachers work motivation, the practice of teaching workforce management, poor quality of data on number of qualified teachers and retirement of experienced teachers (Bulder, 2007). The fundamental shift in the teacher education policy of 1994 was the decentralization and organization of its management from Ministry level down to the Woreda level (cf. Table 1).

There were also other pressing issues in the teacher education program: issues related to quantity and relevance of subject matter knowledge, nonalignment between pre-service teacher education program and the school curriculum, challenges related to program structure, relevance and effectiveness of professional courses, pedagogical content knowledge and concerns related to incentives for good teachers. 
Table 1: Distribution of Responsibility for Teacher Education

\begin{tabular}{|c|c|c|c|}
\hline Ministry of Education & Regional Bureaus & Zonal Bureaus & Woreda Bureaus \\
\hline $\begin{array}{l}\text { Determines the curriculum } \\
\text { of secondary and higher } \\
\text { institutions and assists } \\
\text { regions in curriculum } \\
\text { preparation for the first } \\
\text { and second cycle of } \\
\text { primary education }\end{array}$ & $\begin{array}{l}\text { Recruits qualified } \\
\text { teachers for } \\
\text { secondary, TVET, } \\
\text { TTIs and TTCs } \\
\text { Identifies training } \\
\text { needs. }\end{array}$ & $\begin{array}{l}\text { Ensures that } \\
\text { in-service } \\
\text { training is } \\
\text { given to } \\
\text { teachers and } \\
\text { educational } \\
\text { personnel }\end{array}$ & $\begin{array}{l}\text { Recruits teachers } \\
\text { and other } \\
\text { professionals for } \\
\text { in- service } \\
\text { training and } \\
\text { professional } \\
\text { development. }\end{array}$ \\
\hline $\begin{array}{l}\text { Determines qualifications } \\
\text { of teachers; trains teachers } \\
\text { at secondary and tertiary } \\
\text { levels and educational } \\
\text { personnel, and assists } \\
\text { training programmes of } \\
\text { regions }\end{array}$ & $\begin{array}{l}\text { Trains primary } \\
\text { teachers and } \\
\text { educational } \\
\text { personnel. }\end{array}$ & & $\begin{array}{l}\text { Supervises school } \\
\text { and work with } \\
\text { teachers to } \\
\text { maintain the } \\
\text { educational } \\
\text { standards. } \\
\text { Manages teacher } \\
\text { discipline }\end{array}$ \\
\hline
\end{tabular}

Source: Watson \& Yohannes (2005)

Although the training and education policy of 1994 served as a steppingstone, the different levels of teacher training have passed through various stages of development. Apart from formal training modalities, continuous professional development was designed for strengthening the quality of teachers (Aklilu, Alemayehu \& Mekasha, 2008).

There are many modalities in the teacher-training system. Among others the concurrent or blended model (Bachelor of Education, BED program) teacher training is highly credited in different countries whereas both the consecutive modalities such as add-on model and PGDT and blended or concurrent programmes are practiced in countries like Malaysia, India, Canada, China, South Korea, Taiwan, Hong-Kong and Japan (UNESCO, 1990; Schwille, et al., 2013) use concurrent and consecutive modalities of teacher training.

Since the endorsement of the Ethiopian education and training policy (1994), education sector development programs (ESDPs) have been formulated and implemented in every five year period, within the Ethiopian government strategic plans. In all the ESDPs, attention was given to the teacher training system to provide adequate numbers of qualified teachers to address demand for teachers at all levels of the education system. For instance, the endorsement of Teacher Education System Overhaul (TESO) in 2003 came with a paradigm shift in line with the international trends of active learner-centre training (MOE, 2003, Mekonnen, 2012; Ahmad, 2014; Kedir, 2006). 
However, TESO failed within a short period and the Ministry of Education endorsed new strategies, including a Post Graduate Diploma in Teaching (PGDT), designed for secondary school teachers (Abebe \& Woldehanna, 2013; Semela, 2014). The Post Graduate Diploma in Teaching (PGDT) was endorsed in 2011 in few universities for the purpose of balancing the content and pedagogical gaps of TESO policy (Abebe \& Woldehanna, 2013; Semela, 2014; Kassa \& Amdemeskel, 2013; MOE, 2011). Again the PGDT program has got challenges in many aspects in terms of program structure and curricula, admission discrepancies (Koye, 2014 \& Aweke, 2015). According to Aweke (2015) PGDT students believe that teachers and the teaching profession receive low social respect, which is common in Ethiopia. Awake (2015) further confirms that those teachers are working with poor motivation and they don't want to remain as a teacher for one day if they get the chance to leave the profession.

Based on these realities, the Ministry of education introduced the integrated approach (balanced content and pedagogical approaches) of teacher training with the qualification of Bachelor of Education (BED) with a new structure that sustains quality and professionalization. This study undertook to appraise this approach and, therefore, the teacher training system in the country with specific reference to South West Ethiopia.

\subsection{Conceptual Underpinning}

In conducting the analysis, reference was made to the framework given by Darling-Hammond $(2006,2017)$ and Tacconi and Hunde (2014). These focus on nine components, namely, the social status of the teaching profession; the stand of the teacher-training College; modalities of teacher preparation; program structure and curricula; teacher education pedagogies; teacher education colleges and school partnership; teacher qualification requirements; induction and continuous professional development programmes; and teachers' competence.

The social status of the teaching profession: how stakeholders view the status teachers and teaching profession enjoying compared to other competing professions. These include: teachers professional identity and commitment, salary scale against other competing profession, fringe benefit, academic freedom, career structure and professional development opportunities.

The stand of the teacher-training College: how stakeholders perceive the status and stand of teacher education college and teacher educators compared to other colleges and instructors in higher learning institutes. The indicators are: stand of teacher education college compared to other colleges (resources, staffing's, funds; professional identity of teacher educators (teaching teachers + researching on teaching), teacher educators: policies and practices in relation to recruitment and training of teacher educators, professional preparation of teachers. 
Modalities of teacher preparation: how stakeholders perceive the rigorousness of modalities being used in addressing adequate time for learning contents, pedagogical preparation, and longer school based practices. These include: add on program vs. concurrent program, regular vs. summer in-service, discipline vs. professional area focused preparation.

Program structure and the curricula: how stakeholders perceive and realize the effectiveness of structure of teacher education program in preparing competent and professionally committed teachers. program duration, representativeness of the program contents for development of knowledge bases of teaching, alignment of the curriculum content and practices of different phases of teacher education program so as to avoid counter productiveness ,alignment of teacher education curricula with school curricula and the broader context of teaching in Ethiopian schools.

Teacher education pedagogies: how stakeholders perceive the effectiveness of pedagogies used in teacher education program in effectively and efficiently preparing future teachers. These include: alignment of pedagogies used in teacher education program and key pedagogies emphasized in school curriculum framework, using of pedagogies to support and promote inclusiveness, and the degree to which pedagogies of teaching students with difficulties is being emphasized.

Teacher education colleges and school partnership: how the stakeholders perceive the effectiveness of the current teacher education college and school relationship in allowing the implementation of highly supervised clinical practices for extended period of time. The indicators are: availability of favourable condition for the strong collaboration between university and schools.

Qualification requirements: how stakeholders perceive the appropriateness and effectiveness of requirement set for certifying the would-be teachers to teach. The indicators are: the way the qualification requirement and final examination link the program goal to its different components; link of the program components to the demands of the world of teaching.

Induction and continuous professional program: how do stakeholders the need, effectiveness and appropriateness of induction to bridging teacher education and real world of work as well as the effectiveness of ongoing professional development practices.

Competence of teachers: how stakeholders view on the quality of teachers at pre-primary, primary and secondary school levels for delivery of quality education. these includes: the quality of education across pre-primary schools the quality of education across primary schools ,the quality of education across secondary schools, teachers' normal workload hours per week and professional commitment of teachers.

The conceptual frameworks underline the fact that teachers training system impact on the quality of the classroom environment and the interaction between 
teachers and their students. According to Darling-Hammond (2006, \& 2017) and Tacconi \& Hunde (2014) for development the quality of teacher training; the policy framework requires attention to two types of problems: the quality of teacher-training institutes and efficiency in the process of teachers' pedagogical skill development across schools. Against this background, we delved into the social status of the teaching profession; the stand of the teacher-training College; modalities of teacher preparation; program structure and curricula; teacher education pedagogies; teacher education colleges and school partnership; teacher qualification requirements; induction and continuous professional development programmes; and teachers' competence.

\section{$2 \quad$ Methodology}

The study was conducted in South West Ethiopia where three study sites were selected, namely, Jimma University cluster (Jimma cluster secondary and primary schools, teachers, and principals), Bonga Zone cluster (Bonga cluster secondary and primary schools, teachers, and principals) and Gambella cluster (Gambella cluster secondary and primary schools, teachers, and principals). Cluster sampling techniques were employed (Table 1).

Table 2: Distribution of Participants

\begin{tabular}{llllll}
\hline \multirow{2}{*}{ Participants } & \multirow{2}{*}{ Participant by strand } & \multicolumn{4}{c}{ Study Site } \\
& & Jimma & Bonga & Gambella & Total \\
\hline \multirow{2}{*}{ Teachers } & Primary & 29 & 27 & 31 & 87 \\
& Secondary & 26 & 19 & 24 & 69 \\
\multirow{3}{*}{ Students } & Primary & 31 & 21 & 33 & 85 \\
Total & Secondary & 24 & 20 & 32 & 76 \\
\hline
\end{tabular}

Data was collected using a Likert scale type questionnaire. This focused on teachers' perception of the social status of the teaching profession; modalities of teacher education programs; program structure and curricula; teacher education and school partnership; qualification requirement; processional development and teacher competences. The questionnaire items were adapted from the standard teacher education system analysis frameworks of Darling-Hammond (2006, 2017) and Tacconi and Hunde (2014). The data generated was analysed using descriptive statistics and independent samples t-test. 


\section{Findings, Conclusions and Recommendations}

The findings on perceptions of the social status of the teaching profession are summarized in Table 3.

Table 3: Teachers' social status of teaching profession

\begin{tabular}{|c|c|c|c|c|c|}
\hline \multirow[t]{2}{*}{ Item } & \multirow[t]{2}{*}{$N$} & \multicolumn{2}{|c|}{$\begin{array}{l}\text { Current } \\
\text { situation }\end{array}$} & \multicolumn{2}{|c|}{$\begin{array}{l}\text { Performance } \\
\text { future }\end{array}$} \\
\hline & & Mean & St. Dev & Mean & St. Dev \\
\hline Teaching is the preferred profession & 156 & 2.30 & 1.356 & 4.20 & .098 \\
\hline $\begin{array}{l}\text { Teachers are receiving better salary compared } \\
\text { to other job position with equal educational } \\
\text { status and work experiences }\end{array}$ & 156 & 2.03 & 1.215 & 4.09 & .100 \\
\hline $\begin{array}{l}\text { Teachers are better enjoying fridge benefits } \\
\text { (house allowance, transport allowance, } \\
\text { overtime pay) compare to other equivalent jobs }\end{array}$ & 156 & 2.00 & 1.252 & 4.18 & .095 \\
\hline $\begin{array}{l}\text { Teachers are freely exercising academic } \\
\text { freedom }\end{array}$ & 156 & 2.79 & 1.246 & 4.27 & .078 \\
\hline Teachers' career structure is clear and attractive & 156 & 2.65 & 1.266 & 4.14 & .089 \\
\hline Good opportunities of further education & 156 & 2.85 & 1.324 & 4.30 & .078 \\
\hline $\begin{array}{l}\text { Teachers are receiving need based and relevant } \\
\text { short term training }\end{array}$ & 156 & 2.39 & 1.333 & 4.30 & .076 \\
\hline Aggregate mean & & 2.41 & 1.284 & 4.21 & .087 \\
\hline
\end{tabular}

Table 3 depicts the low teachers' social status of teaching profession. It is expected to do a lot in future teacher development program to address the low status of teaching profession. It is highly demanding area to promote the social status of teaching promotion from the current situation (Mean $=2.41)$ to the highly demanding status (Mean $=4.21)$. 
Table 4: Status of Teacher-Training Colleges

\begin{tabular}{llllll}
\hline Items & \multicolumn{3}{l}{ Current situation } & \multicolumn{2}{l}{ Performance future } \\
\cline { 2 - 6 } & $\mathrm{N}$ & Mean & St. Dev. & Mean & St. Dev. \\
\hline $\begin{array}{l}\text { Teacher education colleges are in a } \\
\text { better position compared to similar } \\
\text { higher learning institutes }\end{array}$ & 156 & 2.69 & 1.249 & 4.15 & .075 \\
$\begin{array}{l}\text { Teacher-trainers are full timers and } \\
\text { they belong to teacher education }\end{array}$ & 156 & 2.82 & 1.281 & 4.11 & .076 \\
$\begin{array}{l}\text { college } \\
\begin{array}{l}\text { Recruitment of teacher educators is } \\
\text { merit based }\end{array}\end{array}$ & 156 & 2.58 & 1.335 & 4.08 & .092 \\
$\begin{array}{l}\text { Good further education opportunities } \\
\text { for teacher educators }\end{array}$ & 156 & 2.99 & 1.333 & 4.30 & .078 \\
$\begin{array}{l}\text { Individuals with no teaching license are } \\
\text { not considered as full-fledged }\end{array}$ & 156 & 2.78 & 1.303 & 3.89 & .098 \\
$\begin{array}{l}\text { instructors } \\
\text { Aggregate mean }\end{array}$ & & & & & \\
\hline
\end{tabular}

Regarding the current situation on status of teacher-training college, Table 4 shows that it is not up to the standard for keeping the pace of quality teacher training. This points to need for positive policy interventions.

Table 5: Modalities of Teacher Education Program

\begin{tabular}{|c|c|c|c|c|c|}
\hline \multirow[t]{2}{*}{ Item } & \multirow{2}{*}{$\mathrm{N}$} & \multicolumn{2}{|c|}{$\begin{array}{l}\text { Current } \\
\text { Situation }\end{array}$} & \multicolumn{2}{|c|}{$\begin{array}{l}\text { Performance } \\
\text { future }\end{array}$} \\
\hline & & Mean & $\begin{array}{l}\text { St. } \\
\text { Dev. }\end{array}$ & Mean & $\begin{array}{l}\text { St. } \\
\text { Dev. }\end{array}$ \\
\hline $\begin{array}{l}\text { PGDT program is preparing competent } \\
\text { teachers for secondary schools }\end{array}$ & 156 & 3.05 & 1.301 & 4.26 & .080 \\
\hline $\begin{array}{l}\text { Summer in-service PGDT program is allowing } \\
\text { preparation of teachers on the subject matter, } \\
\text { and content pedagogies equivalent to regular } \\
\text { program }\end{array}$ & 156 & 2.79 & 1.230 & 4.62 & .097 \\
\hline $\begin{array}{l}\text { Primary Teacher Education Program is } \\
\text { adequate enough in preparing competent } \\
\text { teachers for primary schools }\end{array}$ & 156 & 2.76 & 1.181 & 4.65 & .085 \\
\hline Summer-in-service and extension or weekends & & & & & \\
\hline $\begin{array}{l}\text { Programs are allowing preparation of teachers } \\
\text { on the subject matter contents and content } \\
\text { pedagogies }\end{array}$ & 156 & 2.75 & 1.244 & 4.73 & .094 \\
\hline Aggregate mean & & 2.83 & 1.239 & 4.54 & .089 \\
\hline
\end{tabular}


According to the means in Table 5, the modality of the teacher training program confirms that there is a mismatch between the needs and the practices. The overall modalities of teacher training program need new strategic direction, with exception that regular PGDT program. Therefore, it urges restructuring of the modalities of the teacher training system of summer and extension programs without compromising the maximum competence level of training system.

Table 6: Program Structure and Curricula

\begin{tabular}{|c|c|c|c|c|c|}
\hline \multirow[t]{2}{*}{ Items } & \multirow[t]{2}{*}{$\mathrm{N}$} & \multicolumn{2}{|c|}{$\begin{array}{l}\text { Current } \\
\text { situation }\end{array}$} & \multicolumn{2}{|c|}{$\begin{array}{l}\text { Performance } \\
\text { future }\end{array}$} \\
\hline & & Mean & $\begin{array}{l}\text { Std. } \\
\text { Dev }\end{array}$ & Mean & $\begin{array}{l}\text { St. } \\
\text { Dev }\end{array}$ \\
\hline $\begin{array}{l}\text { Duration of Primary Teacher Education is } \\
\text { adequate enough to prepare quality teachers }\end{array}$ & 156 & 2.79 & 1.161 & 4.11 & .084 \\
\hline $\begin{array}{l}\text { Duration of Secondary Teacher Education } \\
\text { Program is adequate enough to prepare } \\
\text { quality teachers for secondary schools }\end{array}$ & 156 & 2.83 & 1.137 & 4.11 & .088 \\
\hline $\begin{array}{l}\text { The curricula of teacher education program } \\
\text { allows better understanding the nature of } \\
\text { students the would be teachers are going to } \\
\text { teach }\end{array}$ & 156 & 2.79 & 1.166 & 4.13 & .080 \\
\hline $\begin{array}{l}\text { The curriculum of the existing program allows } \\
\text { better mastery of subject matter contents } \\
\text { they are going to teach }\end{array}$ & 156 & 2.82 & 1.145 & 4.19 & .080 \\
\hline $\begin{array}{l}\text { The curriculum of teacher education program } \\
\text { allows the mastery of pedagogies appropriate } \\
\text { school teaching }\end{array}$ & 156 & 2.75 & 1.144 & 4.24 & .076 \\
\hline Teacher education pedagogies & 156 & 2.93 & 1.201 & 4.27 & .068 \\
\hline $\begin{array}{l}\text { Pedagogies used in teacher education } \\
\text { program is aligned with key pedagogies } \\
\text { emphasized and used in school curriculum }\end{array}$ & 156 & 2.65 & 1.271 & 4.17 & .085 \\
\hline Aggregated & & 2.79 & 1.175 & 4.174 & .080 \\
\hline
\end{tabular}

Table 6 shows that the current situation and future demand of teacher education program structure and curricula is too disparate, with the aggregate mean (Current situation mean $=2.79$ ) and (future performance mean $=4.174)$. The program structure and curricula of teacher education is less congruent with the demands of stakeholders. The overall results of Table 4 show that the current program structure and curricula of teacher education is not adequate. It needs new sets of program structure and curricula of teacher education that ensures quality and relevant teacher development programs for the country. 
Table 7: Teacher Education and School Partnership

\begin{tabular}{|c|c|c|c|c|c|}
\hline \multirow[t]{2}{*}{ Item } & \multirow[t]{2}{*}{$\mathrm{N}$} & \multicolumn{2}{|c|}{$\begin{array}{l}\text { Current } \\
\text { situation }\end{array}$} & \multicolumn{2}{|c|}{$\begin{array}{l}\text { Performance } \\
\text { future }\end{array}$} \\
\hline & & Mean & $\begin{array}{l}\text { Std. } \\
\text { Dev }\end{array}$ & Mean & $\begin{array}{l}\text { Std. } \\
\text { Dev }\end{array}$ \\
\hline $\begin{array}{l}\text { Teacher educators and school teachers are } \\
\text { collaborating on teaching, staff development } \\
\text { and research }\end{array}$ & 156 & 2.68 & 1.279 & 4.19 & .079 \\
\hline $\begin{array}{l}\text { School mentors are strongly supporting } \\
\text { student teachers during practicum }\end{array}$ & 156 & 2.84 & 1.298 & 4.13 & .089 \\
\hline $\begin{array}{l}\text { Practicum allows student teachers learn } \\
\text { teaching by doing activities school teachers } \\
\text { and mentors are doing for the extended } \\
\text { period of time }\end{array}$ & 156 & 2.90 & 1.289 & 4.29 & .067 \\
\hline $\begin{array}{l}\text { Well experienced and competent mentors are } \\
\text { selected and guiding student teachers }\end{array}$ & 156 & 2.81 & 1.330 & 4.21 & .085 \\
\hline Aggregate mean & & 2.807 & 1.299 & 4.205 & .080 \\
\hline
\end{tabular}

According to Table 7, there is huge gap between the current situation ( $\mathrm{M}=2.8)$ and future performance $(\mathrm{M}=4.2)$ of teacher education and school partnership. There is a loose relationship of teacher education with partnership. It means that either there no policy guideline and structure that link teacher education with other partner or there may be limited capacity of teacher education to work with partners. This implies need to do more on teacher education with school partnerships in future practices.

Table 8: Qualification Requirement

\begin{tabular}{lccccc}
\hline \multicolumn{1}{c}{ Attributes } & $\mathrm{N}$ & \multicolumn{2}{c}{ Current situation } & \multicolumn{2}{c}{ Performance future } \\
\cline { 3 - 6 } & & Mean & Std. Dev & Mean & Std. Dev \\
\hline $\begin{array}{l}\text { Exit exam ensures certification of } \\
\text { competent teachers }\end{array}$ & 156 & 2.88 & 1.276 & 4.17 & .091 \\
$\begin{array}{l}\text { Exit exams systematically link } \\
\text { program components with }\end{array}$ & 156 & 2.80 & 1.280 & 4.19 & .088 \\
$\begin{array}{l}\text { requirement in the world of } \\
\text { teaching }\end{array}$ & & & & & \\
\begin{tabular}{l} 
Aggregate mean \\
\hline
\end{tabular} & & 2.84 & 1.278 & 4.18 & .089 \\
\hline
\end{tabular}

The results in Table 8 show that the stakeholders were uncertain of qualification requirements for teacher development. The current qualification requirement for teacher education is perceived as uncertain on exit exam $(\mathrm{M}=2.84)$. It means that even though the Ministry of education is planning an exit exam policy to be endorsed in all levels of teacher qualification frameworks, stakeholder are 
unaware of the requirement of exit policies and procedures. However, it is remarked as important $(\mathrm{M}=4.18)$ in future teacher training programs.

Table 9: Processional Development

\begin{tabular}{llllll}
\hline Items & $\mathrm{N}$ & \multicolumn{2}{c}{ Current situation } & \multicolumn{2}{l}{ Performance future } \\
\cline { 3 - 6 } & & Mean & St Dev & Mean & $\begin{array}{c}\text { Std. } \\
\text { Dev }\end{array}$ \\
\hline $\begin{array}{l}\text { Induction program is successfully } \\
\text { bridged the transition of new }\end{array}$ & 156 & 2.87 & 1.286 & 4.16 & .085 \\
$\begin{array}{l}\text { teachers from college to school } \\
\begin{array}{l}\text { Ongoing professional } \\
\text { development practices are }\end{array}\end{array}$ & 156 & 3.19 & 1.288 & 4.28 & .074 \\
$\begin{array}{l}\text { effective in keeping teachers } \\
\text { improve their teaching knowledge }\end{array}$ & & & & & \\
$\begin{array}{l}\text { and skills } \\
\text { Aggregate mean }\end{array}$ & & & & & \\
\hline
\end{tabular}

Table 9 shows that ongoing professional development practices on the current situation $(M=3.18)$ were better preferred to induction programs $(M=2.87)$. The computed mean $(\mathrm{M}=03)$ shows that professional development is better than other teacher capacity building modalities. However, the findings show that a lot needs to be done on both induction and ongoing professional development $(\mathrm{M}=4.22$, $\mathrm{SD}=.080$ ) or future teacher training programs. Table 10 further describes the nature of professional development that teachers want to acquire more for future strategic development. 
Table 10: Independent T-test for differences in teacher competence

\begin{tabular}{|c|c|c|c|c|c|c|}
\hline Competence Items & Participant & $\mathrm{N}$ & $\begin{array}{l}\text { Current Situation } \\
\text { Mean }\end{array}$ & $\begin{array}{l}\text { Performance Future } \\
\text { Mean }\end{array}$ & T-test & $P$ value \\
\hline Understanding characteristics of the target students & teachers & 156 & 3.03 & 4.31 & & \\
\hline Understanding how students learn and develop & teachers & 156 & 3.17 & 4.47 & & \\
\hline \multirow[t]{2}{*}{ Understanding the goal of the school curriculum } & students & 161 & 2.82 & 4.02 & -1.795 & .0 .074 \\
\hline & teachers & 156 & 3.1 & 4.37 & & \\
\hline \multirow{2}{*}{$\begin{array}{l}\text { Mastery of pedagogical principles and methods } \\
\text { relevant for teaching school contents }\end{array}$} & students & 161 & 2.71 & 3.91 & -3.944 & $.000 *$ \\
\hline & teachers & 156 & 3.19 & 4.44 & & \\
\hline \multirow[t]{2}{*}{ Planning for effective learning for students } & students & 161 & 2.7 & 4.05 & -3.944 & $.000^{*}$ \\
\hline & teachers & 156 & 3.31 & 4.47 & & \\
\hline Facilitating learning-centred innovative methods & students & 161 & 2.35 & 4.04 & -3.889 & $.000 *$ \\
\hline $\begin{array}{l}\text { Assessing and monitoring learning process and } \\
\text { outcomes }\end{array}$ & teachers & 156 & 2.62 & 4.37 & & \\
\hline \multirow[t]{2}{*}{ Aggregated mean } & students & 161 & 2.633 & 4.391 & -3.241 & $.000 *$ \\
\hline & teachers & 156 & 3.271 & 4.313 & & \\
\hline
\end{tabular}


From Table 10, it can be recalled that significant differences regarding teacher competences were observed among the teachers $(\mathrm{M}=2.633)$ and their students $(\mathrm{M}=3.271)$. However both are demanding more to do on teacher competences in future teacher training programs.

Overall, these findings point to three major recommendations:

1. Revisiting the current career structure for teachers with the view to mitigate the current profiling of teachers and the teaching profession as characteristically of low social status. This may be achieved through improving teachers' conditions of service, especially rewards

2. Reformulating the teacher training system with the view to better tailor its modalities, curriculum and program structure to contemporary needs.

3. Establishing a quality assurance system for any modality of teacher training system that controls the optimum quality standard for general education teacher competence.

\section{Acknowledgement}

The authors gratefully acknowledge the financial support of Jimma University; all the teachers and students who participated in the study; and the persons that coordinated the study at the various study sites.

\section{References}

Abebe, W. Woldehanna, T. (2013). Teacher Training and Development in Ethiopia Improving Education Quality by Developing Teacher Skills, Attitudes and Work Conditions. London: Young Lives.

Ahmad, S. (2014). Teacher Education in Ethiopia: Growth and Development. Afr. J. Teacher Educ. 3(3).

Aklilu, D. Alemayehu, T., \& Mekasha, K. (2008). The structure and content of secondary school teacher education program: International and national experiences. Journal of Education for development volume II, No. 2

Bulder J. (2007). Country Analysis of Education, Ethiopia, Cambridge J. Educ. 44(1), 113-145.

Darling-Hammond, L. (2017).Teacher education around the world: What can we learn from international practice? European Journal of teacher education, 40(3), 291-209.

Darling-Hammond, L. (2006). Constructing $21^{\text {st }}$ Century Teacher Education. Journal of Teacher Education, 57(3), 300-314.

Hunde, A., Tacconi, G. (2014). Pulling and pushing Forces for ICT in initial Teacher Preparation for Secondary Schools. US-China Education Review, 3(10), 707-721. 
Kassa, K., Amdemeskel, Y. (2013). Practices and Challenges of Postgraduate Diploma in Teaching (PGDT) Programme: The Case of Haramaya University. Kedir, A. (2006). Contradictions, challenges, and chaos in Ethiopian teacher education. J. Critical Educ. Policy Stud. 4(1).

Koye, K. (2014). Attitude of Postgraduate Diploma in Teaching (PGDT) Student Teachers towards Teaching Profession in Ethiopian University College of Teacher Education. Middle Eastern \& African Journal of Educational Research, Issue 7.

Mekonnen, T. (2017). The Current Teacher Education Programs in Ethiopia: Reflection on Practice. Academic Journal of Education 12(6), 366-372

Ministry of Education (2011). Postgraduate diploma in teaching (PGDT) Addis Ababa, Ethiopia

Ministry of Education. (2008). General Education Quality Improvement Program. Addis Ababa University, Ethiopia.

Ministry of Education (2003). Teacher Education System Overhaul (TESO) Handbook. Addis Ababa, Ethiopia.

Ministry of Education (2002). Education Sector Development Programme Action Plan-II Addis Ababa, Ethiopia.

Ministry of Education (1998). Education Sector Development Programme Action Plan-I. Addis Ababa, Ethiopia.

Ministry of Education (1994). Transitional Government of Ethiopia Education Sector Strategy. Addis Ababa, Ethiopia.

Schwille, J., Tatto, T., M., Rowley, M., Peck, R., Senk, L. S. (2013). An Analysis of Teacher Education Context, Structure, and Quality- Assurance Arrangements in TEDS-M Countries. International Association for the Evaluation of Educational Achievement. Australian Council for Educational Research Michigan State University.

Semela, T. (2014). Teacher preparation in Ethiopia: A critical analysis of reforms. Cambridge J. Educ. 44(1), 113-145.

UNESCO. (1990). Innovations and initiatives in teacher education in Asia and the pacific region, Volume2: case studies. Bangkok.

Watson, D., Yohannes, L. (2005). Capacity Building for Decentralized Education Service Delivery in Ethiopia, (Discussion Paper 57H). Maastricht: European Centre for Development Policy Management. 